\title{
Numerical investigation of soot mass concentration in compression ignition diesel engine
}

\author{
F. Ibrahim ${ }^{1,2}$, W.M.F. Wan Mahmood ${ }^{1 *}$, S. Abdullah ${ }^{1}$ and M.R. Abu Mansor ${ }^{1}$ \\ ${ }^{1}$ Department of Mechanical and Materials Engineering, Faculty of Engineering and \\ Built Environment, Universiti Kebangsaan Malaysia, 43600 Bangi, Selangor, Malaysia. \\ ${ }^{2}$ Mechanical and Aerospace Technology Division, Science and Technology Research \\ Institute for Defence (STRIDE), 43000 Kajang, Selangor, Malaysia. \\ *Email: faizal.mahmood@ukm.edu.my \\ Phone: +60389216513; Fax: +60389252546
}

\begin{abstract}
Soot particles, carbon monoxide, oxides of nitrogen, oxides of sulphur, and hydrocarbon are the emissions produced from diesel engine combustion. Those emissions species are undesirable since they give detrimental impacts to the atmosphere and human well-being. Several numerical investigations conducted by various researchers provide different soot mass concentration values. As an alternative, this study was carried out to investigate the soot mass level produced by a single cylinder diesel engine, using a commercial multidimensional computational fluid dynamic software. The result obtained from simulation effort was then validated by experimental testing during the same engine condition (engine speed of $1600 \mathrm{rpm}$ at $40 \%$ load). Soot mass predicted by simulation gives a value of $3.43 \times 10^{-8} \mathrm{~kg}$ at end of simulation, while measured soot mass via experimental testing gives a value of $1.52 \times 10^{-8} \mathrm{~kg}$. Both results differ by $56 \%$ thus indicating that the simple soot model applied was not sufficient to represent the actual soot mass emitted through exhaust manifold. This leads to the conclusion that more detailed soot model is needed to make the simulation results more meaningful and comparable to the experimental testing.
\end{abstract}

Keywords: Soot; diesel engine; CONVERGE CFD; Hiroyasu-NSC; soot model.

\section{INTRODUCTION}

Global increase in the total number of on-road vehicles triggers the growing problem of air pollution due to exhaust emissions. Although the efforts in reducing and controlling the vehicle emissions are continuously undertaken all around the globe, it seems to be insufficient at this moment. More significant investigations and testing need to be carried out to ease the problem. Besides carbon monoxide (CO), oxides of nitrogen (NOx), oxides of sulphur (SOx), and hydrocarbon (HC), soot is another emission produced from diesel engine combustion [1-3]. As a major part of particulate matters (PM), it is undesirable as it gives bad impact to the atmosphere and human well-being. Soot and other exhaust emissions were proven to cause global warming, acid rain, smog, odours, respiratory and other health hazards [4-6]. Various researchers successfully demonstrated the poisonous effect of soot that affected human health [7-10] and its effect of decreasing the overall engine performances [11-14]. The pioneer countries in enforcing the emission control such US, Europe, Japan and China have become an example for other developing countries to do the same. European countries, for example, have taken appropriate actions to stringent the emission regulation for their government as summarised in Table 1 
(example given is for light duty diesel powered vehicle or passenger car, GVW $\leq$ $2500 \mathrm{~kg})$.

Table 1. Emission Standards implemented by European countries [15, 16].

\begin{tabular}{cccc}
\hline Standard & Date Implemented & $\begin{array}{c}\text { Particulate Mass } \\
(\mathrm{g} / \mathrm{km})\end{array}$ & $\begin{array}{c}\text { Particulate Number } \\
(\# / \mathrm{km})\end{array}$ \\
\hline Euro 1 & July 1992 & 0.14 & - \\
Euro 2 & January 1996 & 0.08 & - \\
Euro 3 & January 2000 & 0.05 & - \\
Euro 4 & January 2005 & 0.025 & - \\
Euro 5a & September 2009 & 0.005 & - \\
Euro 5b & September 2011 & 0.005 & $6 \times 10^{11}$ \\
Euro 6 & September 2014 & 0.005 & $6 \times 10^{11}$ \\
\hline
\end{tabular}

Since decades ago, numerous techniques were introduced by researchers, manufacturers and government agencies with the aim to eliminate the emissions effects by improving the engine technologies, exhaust after-treatment devices and renewable energy enhancement [17-23]. Details physical and chemical characteristics of soot and other emissions from their multiple sources - in-cylinder, in exhaust and in-oil, are still actively debated and continuously investigated either experimentally or computationally $[24,25]$. Although computational analyses require further validation process, its undisputable advantages in terms of time and cost saving should not be neglected. Furthermore, modern computer programs nowadays have been developed with high environment. Examples given here are the researchers who investigated the emissions characteristics but with various engine parameters using different computer software such as KIVA [26-32], Star-CD [33-35], open foam CFD [36, 37], AVL FIRE [38, 39], Converge CFD [40, 41] and also ANSYS Fluent [42-45]. Although there are many investigations conducted through several simulation software, the results reporting on soot mass concentration are varied. Therefore, as an alternative, this study is carried out using a commercial Computational Fluid Dynamic (CFD) software, CONVERGE CFD. This software is relatively recent, and its capability has not been fully explored. The objective of this study is to investigate the in-cylinder soot mass concentration via its formation and oxidation process, within pre-set engine conditions using a specific soot model.

\section{METHODS AND MATERIALS}

\section{Pre-Processing Setup}

In this paper, the combustion process of a single-cylinder diesel engine was simulated using multidimensional CFD software, CONVERGE CFD. This software was developed by Convergent Science Inc, initiated by engine simulation experts, which purposely can be used for both engine and non-engine simulations. The simulation is based on the inhouse direct injection diesel engine, Yanmar TF90M. This horizontal, single cylinder, 4 cycles, water-cooled diesel engine is mainly used for agricultural purposes. The engine has a bowl-in-piston and the schematic diagram for crown piston configuration is shown in Figure 1. The simulation was carried out for the close-cycle combustion environment from inlet valve closing (IVC) at $-168^{\circ}$ Crank Angle (CA) After Top Dead Centre (ATDC) to exhaust valve opening (EVO) at $138^{\circ} \mathrm{CA}$ ATDC. The detailed specification 
of the engine, operating conditions, and initial conditions used in the software is shown in Tables 2-4.

Table 2. Diesel engine specification.

\begin{tabular}{lc}
\hline \multicolumn{1}{c}{ Parameters } & Specifications \\
\hline Engine type & Water-cooled 4 cycle \\
Engine capacity $(\mathrm{cc})$ & 493 \\
Number of cylinder & 1 \\
Bore $\times$ Stroke & $85 \times 87 \mathrm{~mm}$ \\
Injection system & Direct injection \\
Injection nozzle $(\mathrm{n} \times \varnothing \mathrm{d})$ & $4 \times \varnothing 0.22 \mathrm{~mm}$ \\
Compression ratio & $18.0: 1$ \\
\hline
\end{tabular}

Table 3. Engine operating condition.

\begin{tabular}{lc}
\hline \multicolumn{1}{c}{ Parameters } & Specifications \\
\hline Engine speed & $1600 \mathrm{rpm}$ (max. torque) \\
Initial Swirl ratio & 1.8 \\
Start of Injection (SOI) & $-18^{\circ} \mathrm{ATDC}$ \\
Injection period & $10^{\circ}$ \\
Injection pressure & $196 \mathrm{bar}$ \\
Injection quantity & $19 \mathrm{mg}$ \\
\hline
\end{tabular}

Table 4. Engine initial conditions.

\begin{tabular}{lc}
\hline \multicolumn{1}{c}{ Parameters } & Specifications \\
\hline In-cylinder temperature & $315 \mathrm{~K}$ \\
In-cylinder pressure & $105 \mathrm{KPa}$ \\
Piston head temperature & $363 \mathrm{~K}$ \\
Cylinder liner temperature & $319 \mathrm{~K}$ \\
Piston temperature & $403 \mathrm{~K}$ \\
\hline
\end{tabular}

Model of the combustion chamber was firstly generated using computer aided design (CAD) software, Siemens Unigraphic NX 10.0 before it was exported to the preprocessing software, CONVERGE CFD for the geometry checking and clean-up [46]. Figure 2 shows the model of combustion chamber created by Unigraphic NX 10.0 and then cleaned-up by CONVERGE CFD.

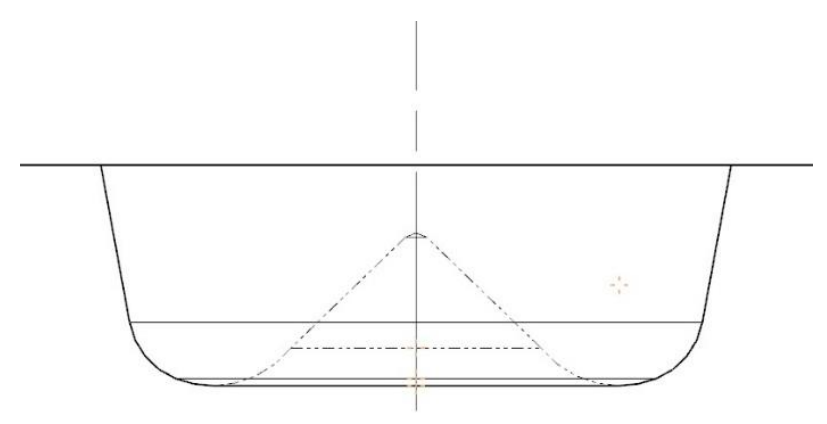

Figure 1. Piston bowl diagram. 

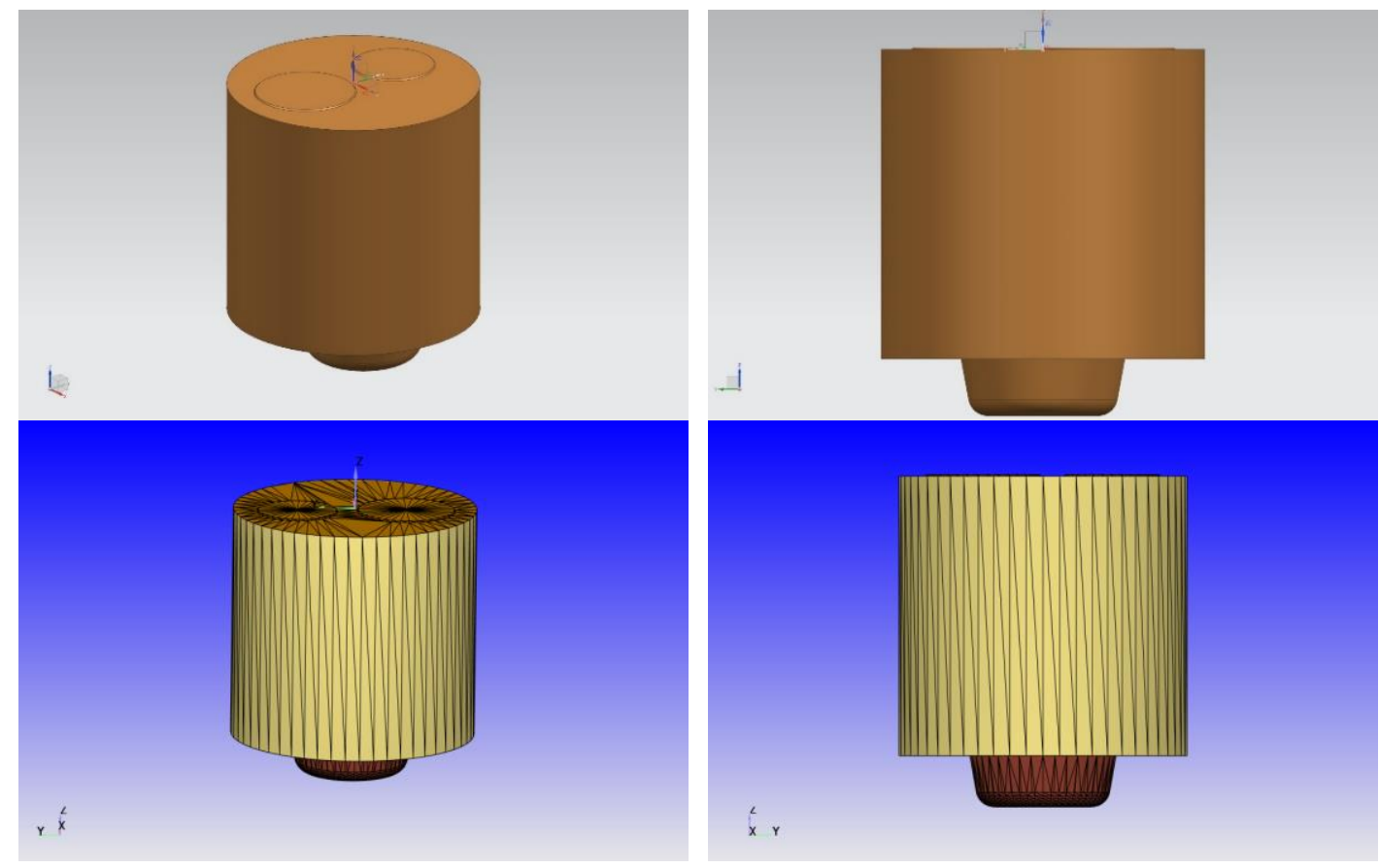

Figure 2: Model of the combustion chamber created by Unigraphic NX 10.0 (above) and cleaned-up by CONVERGE CFD (below).

\section{Mathematical Modelling}

Using relatively simple soot model as a solver, net soot mass was simulated during the combustion process. Soot formation processes were solved by Hiroyasu soot formation [47], coupled with the Nagle and Strickland-Constable (NSC) [48] soot oxidation expressions. Soot formation equation can be written as [49];

$$
\frac{d M_{s f i}}{d t}=N M_{f v i} P_{i}^{0.5} e^{\left(-E_{s f} / R T_{i}\right)}
$$

where $M_{s f i}$ is the soot formation concentration, $d t$ is the time step interval, $N$ is soot particle formation multiplication factor, $M_{f v i}$ is the fuel vapour concentration (considered as source of soot formation), $P$ is the pressure, $E_{s f}$ is the activation energy for soot formation $(12,500 \mathrm{cal} / \mathrm{mole}), R$ is the gas constant (1.987), and $T$ is the in-cylinder temperature. The current time step is represented by $I$, while soot oxidation process equation can be written as follows [44];

$$
\stackrel{\circ}{R}_{N S C}=\left[\frac{k_{A} p}{\left(1+k_{z} p\right)}\right] x+k_{B} p(1-x)
$$

where $x$ is the surface fraction covered by more reactive side on the carbon surface (namely as A) and 1-x is the fraction covered by less reactive side (namely as B).

The two-step model of soot calculation is considered sufficient for this investigation. Considering n-heptane $\left(\mathrm{C}_{7} \mathrm{H}_{16}\right)$ as fuel, the reaction mechanism which contains 4 elements and 42 species is applied in this study to model diesel combustion chemistry. In addition to the soot model, other dedicated sub-models are used to solve 
each sub-process, including spray breakup, turbulence, and combustion. These submodels are listed in Table 5.

Table 5. The computational sub-models applied.

\begin{tabular}{lc}
\hline \multicolumn{1}{c}{ Phenomenon } & Model \\
\hline Soot formation & Hiroyasu-NSC [47, 48] \\
NOx formation & Extended Zeldovich [50] \\
Spray breakup & KH-RT model [51, 52] \\
Drop drag & Dynamic model [53] \\
Collision and coalescence & NTC model [54] \\
Spray-wall interaction & Rebound/slide model [55, 56] \\
Vaporization & Multi component fuel \\
Turbulence & RNG k-E model [57] \\
Combustion & SAGE [58] \\
\hline
\end{tabular}

All these mathematical models are executed by solver and the results can be visualised using post-processing software, EnSight 10.1. This particular post-processor is primarily designed to animate or visualise the complex datasets obtained from computational analyses [59]. In this case, all the calculated results regarding soot mass as well as other gas emissions are well executed and presented in the next section.

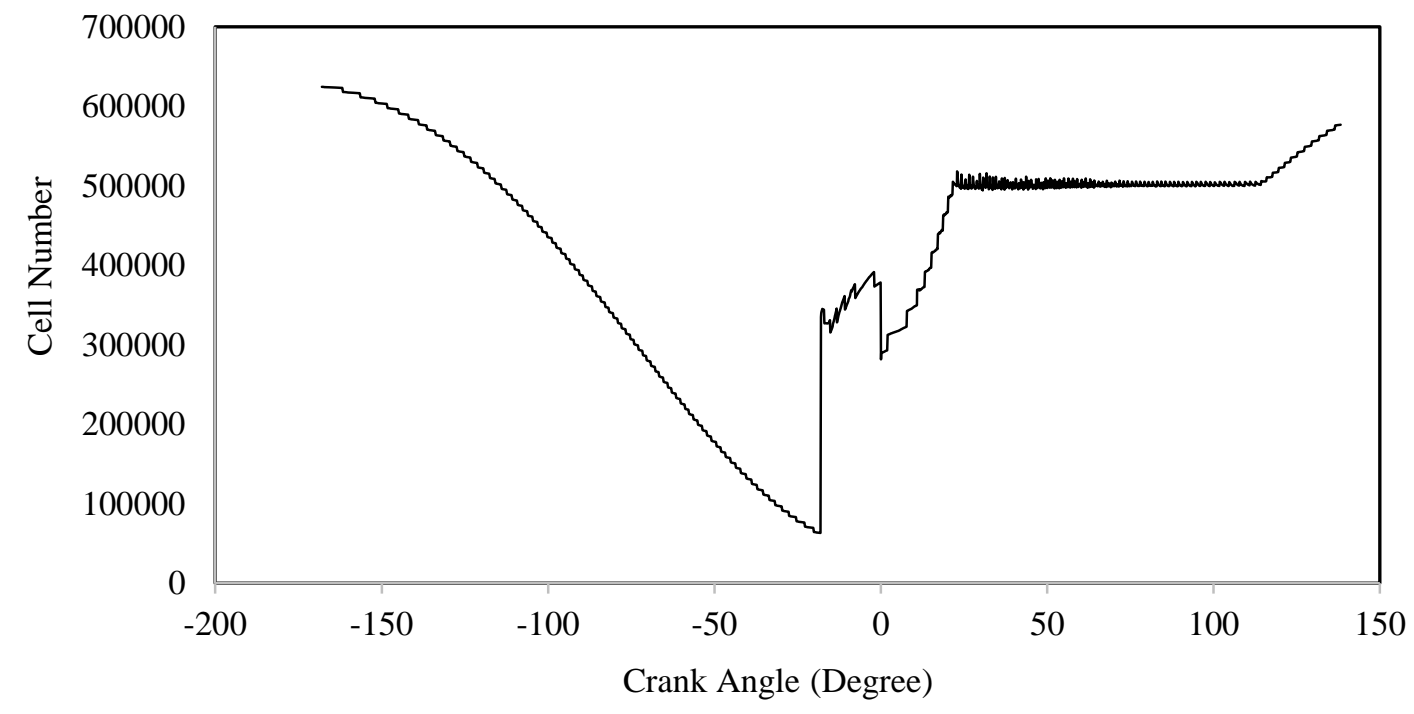

Figure 3. Total cells used in the simulation.

\section{Mesh Setup}

In this study, the overall mesh resolution of $1.0 \mathrm{~mm}$ was found to sufficiently produce grid independent results, as the comparison of different mesh sizes is clearly discussed in [60]. Meanwhile, injector region which is considered as the most important segment was set to $0.375 \mathrm{~mm}$ of mesh size. The meshing size for injector region will only be activated from $-18^{\circ} \mathrm{CA}$ onwards. This extra feature of the software so-called Adaptive Mesh Refinement (AMR) reduces the computational time significantly as it allows users to customise their mesh setup according to certain spatial and temporal conditions. Figure 3 shows the number of total cells of 624,556 during the start of the simulation and it keeps decreasing to the lowest number of 63,726 due to compression stroke of the engine. The 
number of cells suddenly increases when AMR feature is activated and it keeps increasing until reaching its end value of 576,858 during the expansion stroke of the engine. This total cell number used indicates its effect during the critical simulation time (the start of ignition and through combustion process). As the smaller cell size used will increase the total cell number, hence more accurate calculation is expected.

\section{Experimental Validation}

As to validate the net soot mass obtained from computational analysis, an experimental testing was conducted during the same engine condition (engine speed of $1600 \mathrm{rpm}$ at $40 \%$ load). A combustion analyser, DEWE-5000, was facilitated to measure the incylinder pressure of the engine. Meanwhile for soot mass calculation, smoke opacity was measured during the engine running by Bosch analyser, BEA 350. The conversion of opacity measured to soot mass concentration using Alkidas equation [61] is as below;

$$
\begin{aligned}
& B n=N \times 10 \\
& C=581.4\left[\ln \left(\frac{10}{10-B n}\right)\right]^{1.413}
\end{aligned}
$$

where $B n$ is Bosch number (in range 1 to 10 ), $N$ is opacity in $\%$, and $C$ is soot mass concentration in $\mathrm{mg} / \mathrm{m}^{3}$. This soot mass concentration is then multiplied by the in-cylinder volume during EVO $\left(0.000478 \mathrm{~m}^{3}\right)$ to acquire soot mass at that time. Finally, the soot mass measured by the equation is compared with soot mass concentration obtained by simulation. The experimental result obtained at exhaust manifold is assumed to be representable to the simulation result at EVO.

\section{RESULTS AND DISCUSSION}

\section{In-cylinder Pressure Effects}

In-cylinder pressure is the greatest factor affecting any parameters on the sooting process by increasing all of the reaction rates involved in soot formation and oxidation. As pressure is increased, the rate of oxidation increases more rapidly than the rate of formation [62]. In order to discuss the effect of the pressure to the soot mass concentration in the next sub-section, the changes of this variable both from simulation and experimental setup are plotted and shown in Figure 4. Calculated pressure by simulation shows very well agreed with the experimental result, which leads to the assumption that net soot mass predicted by computational analysis are considerably similar to the actual result by experimental testing. Therefore, the changes of pressure values directly affect all of the reaction rates involved in soot formation and oxidation process as explained in the subsequent sub-section.

\section{Soot Mass Concentration}

Based on Hiroyasu soot model, net soot mass, $m_{s}$ is calculated by competition between soot mass formation rate and the soot mass oxidation rate, as follows [63];

$$
\frac{d m_{s}}{d t}=\left(\frac{d m_{s}}{d t}\right)_{\text {formation }}-\left(\frac{d m_{s}}{d t}\right)_{\text {oxidation }}
$$


Results from this mathematical model are clearly demonstrated in Figure 5. Soot formation begins concurrently with soot oxidation process just right after SOI takes place at $-18^{\circ}$ ATDC. Both processes keep increasing with different process rates. Based on Eq. (3), net soot mass can be calculated and plotted. At the first stage, soot formation rate is higher than oxidation rate, thus resulting the net soot mass to keep increasing until its maximum value of $1.21 \times 10^{-7} \mathrm{~kg}$ during $26.8^{\circ} \mathrm{CA}$. Then, soot formation rate starts to stabilise while oxidation rate is still in the increasing trend, thus making the net soot mass start to decrease until its final value of $3.43 \times 10^{-8} \mathrm{~kg}$ at the end of the simulation (EVO). This end value of the net soot mass is very important since it is considered to be the mass that emitted to the atmosphere through exhaust pipe.

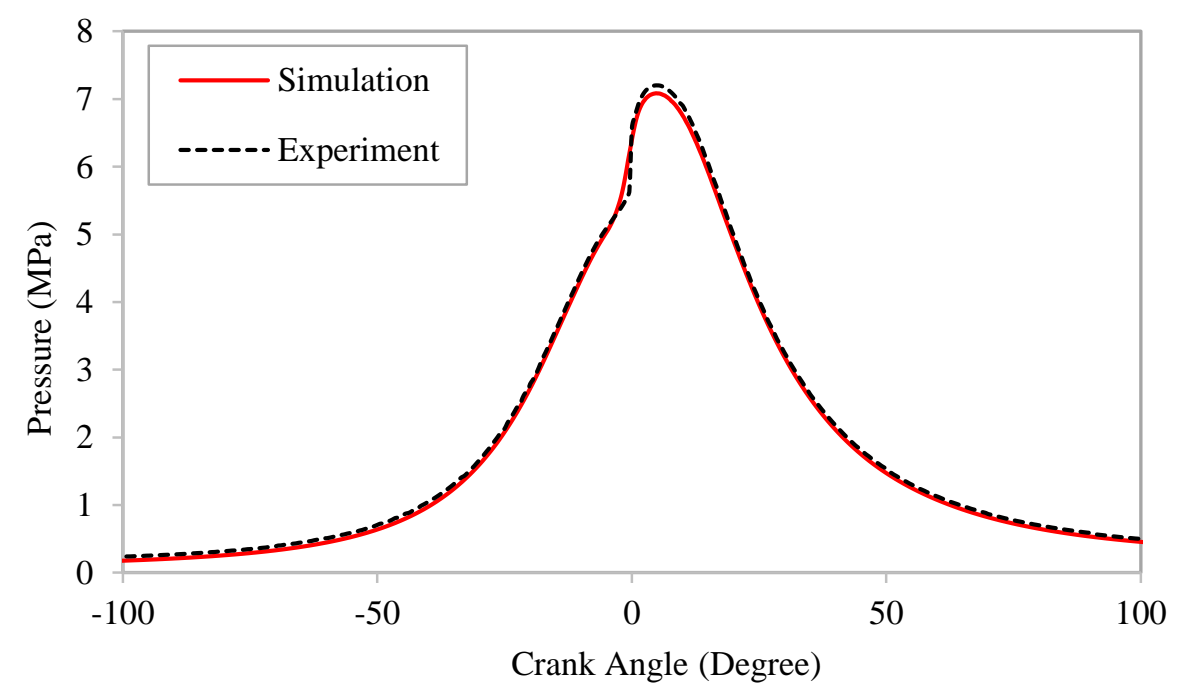

Figure 4. In-cylinder pressure comparison between experimental and computational result.

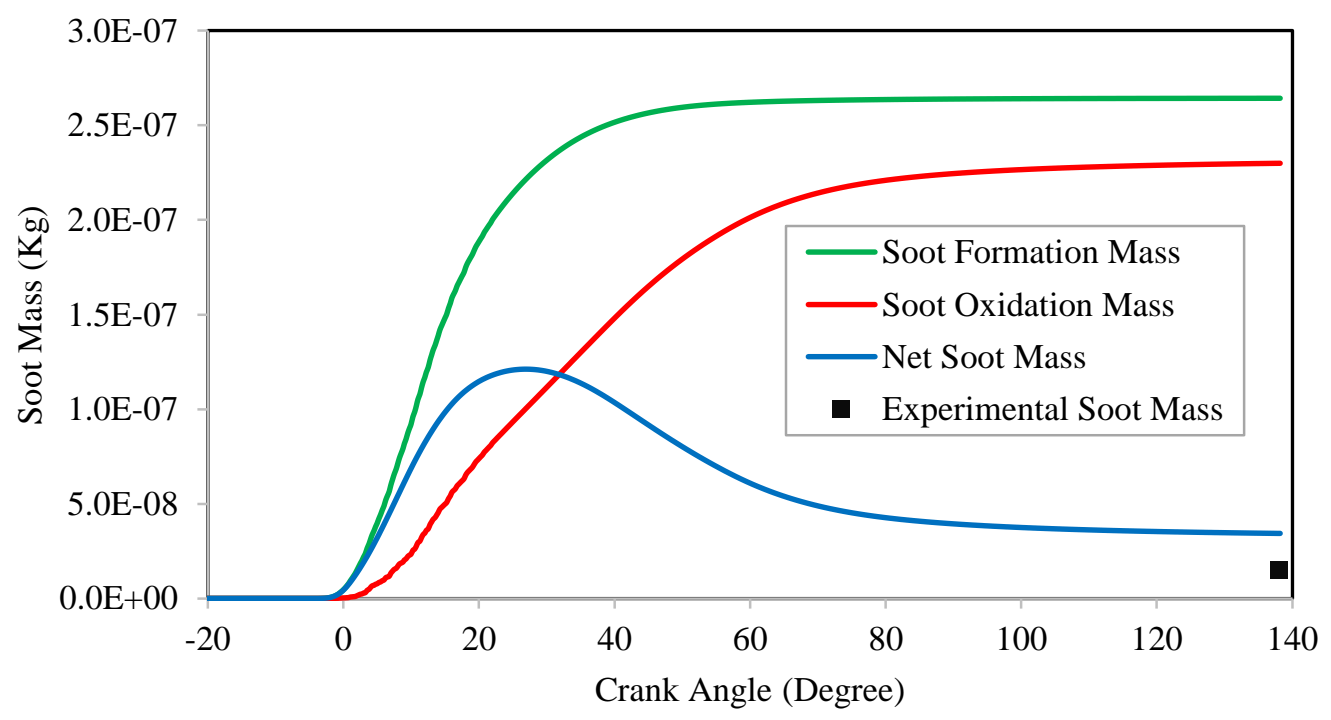

Figure 5. Soot mass calculation based on Hiroyasu soot model and comparison to the experimental soot mass. 
This value is then compared to the experimental result which is calculated by substituting the opacity conversion number into Alkidas equation. In this case, opacity measured was $12 \%$, thus providing net soot mass concentration, $C=31.78 \mathrm{mg} / \mathrm{m}^{3}$. Hence, the value of net soot mass at EVO with the volume, $v=0.000478 \mathrm{~m}^{3}$ will be, $m=1.52 \times$ $10^{-8} \mathrm{~kg}$. This measured value is different to the predicted value from simulation by $56 \%$ error. The large variation of this end value is primarily due to simple soot model applied, which does not take into account other important soot sub-process (nucleation, condensation and coagulation) [60,64]. Although the simulation results obtained here do not sufficiently represent the experimental result, it is still within the soot mass range as reported by Symonds et. al (2007) [65].

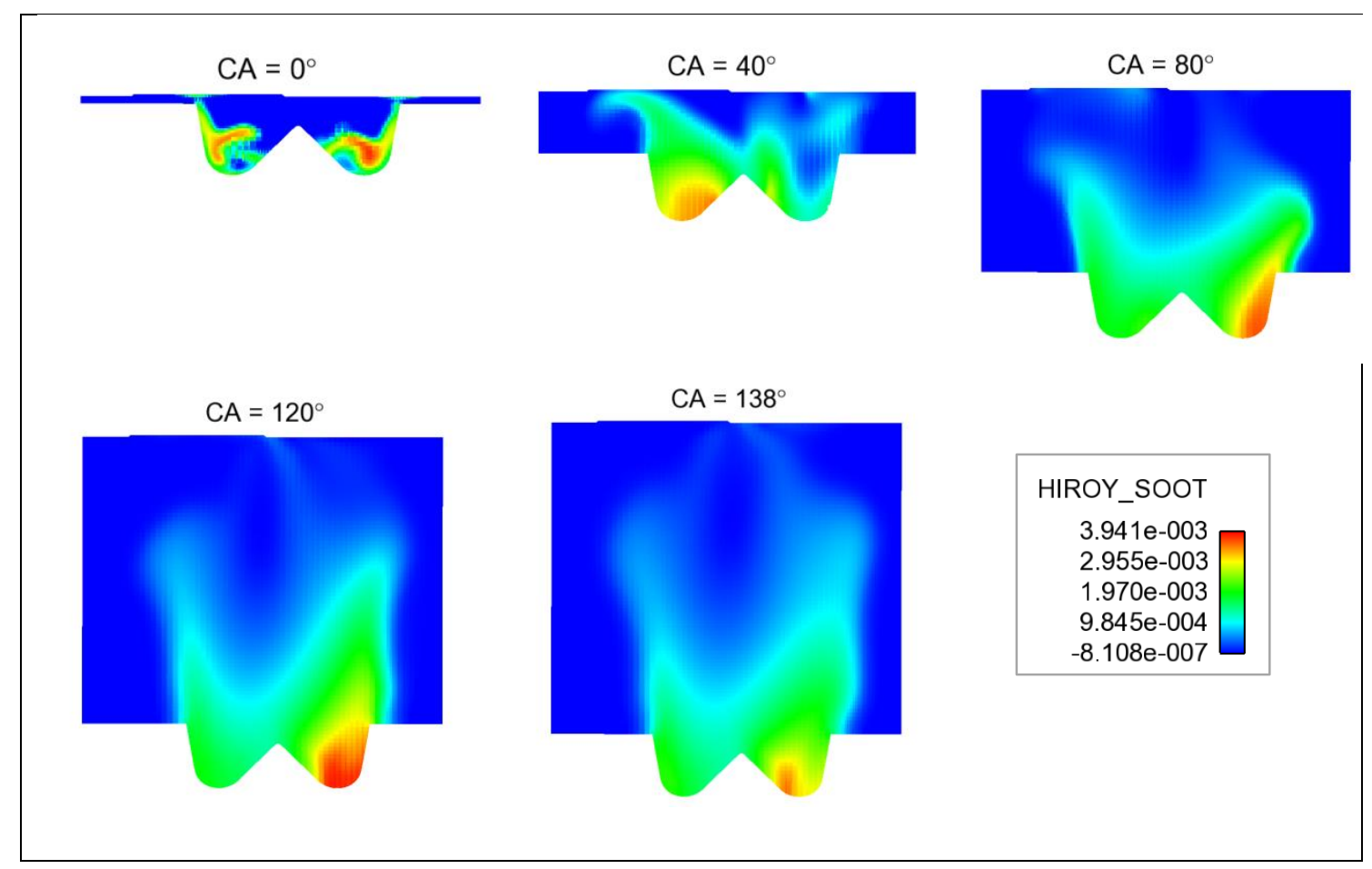

Figure 6. Soot mass concentration in combustion chamber along the simulation time.

Figure 6 shows the visualisation of net soot mass concentration on a crosssectional plane view of the combustion chamber, which was post-processed. Plotting from $0^{\circ} \mathrm{CA}$ to EVO, with every $40^{\circ} \mathrm{CA}$ of time interval, it is well comparable to the net soot mass in Fig. 5 during the combustion process. This qualitative result can provide an additional perspective on how the soot mass is distributed and concentrated inside combustion chamber. As depicted in the figure, heavier soot mass value is more concentrated at the centre and bottom part of the cylinder (i.e. squish/bowl region) instead of the upper side of the cylinder. As oxidation rate starts to increase higher than formation rate towards the end of simulation, almost all the lower soot mass values occupy' the upper side and near the cylinder wall. These lighter soot particles are assumed to be emitted during exhaust stroke while a part of it will remain and be deposited onto the cylinder wall. 


\section{CONCLUSIONS}

In this study, investigation for in-cylinder soot mass concentration was carried out to simulate the soot mass concentration within the pre-set engine condition. Net soot mass reached its final value of $3.43 \times 10^{-8} \mathrm{~kg}$ at the end of the simulation (EVO), which indicates that this is the value of soot mass that emitted to the atmosphere during exhaust stroke of the engine. Meanwhile, soot mass value through experimental testing was 1.52 $\times 10^{-8} \mathrm{~kg}$. This makes the predicted value from simulation of $56 \%$ error, due to disregard of the other important soot sub-process (nucleation, condensation, and coagulation). The qualitative results through post-processing method also give an additional viewpoint on how the soot mass is distributed and concentrated inside the combustion chamber. It was depicted that lighter soot mass particles are assumed to be emitted during exhaust stroke while heavier soot mass particles will remain and be deposited onto the cylinder wall.

The present study contributes to the exhaust soot mass concentration in limited close-cycle investigation. Since Hiroyasu-NSC soot model is considered as a simple soot model and it only resolves the two-step equation from overall soot formation process, it is necessary to perform the analysis with a more complex mathematical model that will consider multi-steps equation. This advance soot model can resolve total soot mass, soot size distribution, soot volume fraction, and soot number density. This is to ensure that the results obtained are more comparable to the actual testing, thus providing more meaningful contribution to the exhaust emission regulation. In addition to the study of soot particle in a diesel engine, similar procedure is projected to investigate the soot problem in biodiesel or any other alternative fuels.

\section{ACKNOWLEDGEMENTS}

The authors would like to acknowledge their gratefulness to Ministry of Higher Education of Malaysia for supporting this study through its research grant of FRGS/1/2013/TK01 /UKM/02/2. Special thanks to Mechanical and Aerospace Technology Division, Science and Technology Research Institute for Defence (STRIDE), Ministry of Defence, Malaysia for granting the use of its facilities regarding this project.

\section{REFERENCES}

[1] Muharam Y, Mahendra M, Gayatri D, Kartohardjono S. Simulation of ignition delay time of compressed natural gas combustion. International Journal of Automotive and Mechanical Engineering. 2015;12:3125-40.

[2] Mat MH, Badrulhisam NH, Hanafiah AQ, Abdullah NR, Mamat AMI. Characteristics of K3-Vei4 engine performance using swirl generator, air intake tank and exhaust gas recirculation modification. International Journal of Automotive and Mechanical Engineering. 2015;11:2484-94.

[3] Adam IK, A. Aziz AR, Yusup S. Determination of diesel engine performance fueled biodiesel (rubber seed/palm oil mixture) diesel blend. International Journal of Automotive and Mechanical Engineering. 2015;11:2675-85.

[4] Eastwood P. Particulate emissions from vehicles: John Wiley \& Sons; 2008.

[5] Pulkrabek WW. Engineering fundamentals of the internal combustion engine: Prentice Hall; 2004. 
[6] Gómez-Rico MaF, Martín-Gullón I, Fullana A, Conesa JA, Font R. Pyrolysis and combustion kinetics and emissions of waste lube oils. Journal of Analytical and Applied Pyrolysis. 2003;68:527-46.

[7] Brunekreef B, Holgate ST. Air pollution and health. The lancet. 2002;360:123342.

[8] Kagawa J. Health effects of diesel exhaust emissions - a mixture of air pollutants of worldwide concern. Toxicology. 2002;181:349-53.

[9] Englert N. Fine particles and human health - a review of epidemiological studies. Toxicology Letters. 2004;149:235-42.

[10] Kim K-H, Kabir E, Kabir S. A review on the human health impact of airborne particulate matter. Environment International. 2015;74:136-43.

[11] Woschni G, Huber K. The influence of soot deposits on combustion chamber walls on heat losses in diesel engines. SAE Technical Paper No. 910297; 1991.

[12] Mainwaring R. Soot and wear in heavy duty diesel engines. SAE Technical Paper No. 971631; 1997.

[13] George S, Balla S, Gautam M. Effect of diesel soot contaminated oil on engine wear. Wear. 2007;262:1113-22.

[14] George S, Balla S, Gautam V, Gautam M. Effect of diesel soot on lubricant oil viscosity. Tribology International. 2007;40:809-18.

[15] ECOpoint. Emission standards. DieselNet; 2015.

[16] UNEP. Status of fuel quality and vehicle emission standards in Asia-Pacific. United Nations Environment Programme; 2013.

[17] Ghafoori M, Ghobadian B, Najafi G, Layeghi M, Rashidi A, Mamat R. Effect of nano-particles on the performance and emission of a diesel engine using biodieseldiesel blend. International Journal of Automotive and Mechanical Engineering. 2015;12:3097-108.

[18] Azad AK, Rasul M, Giannangelo B, Islam R. Comparative study of diesel engine performance and emission with soybean and waste oil biodiesel fuels. International Journal of Automotive and Mechanical Engineering. 2015;12:286681.

[19] Dubey P, Gupta R. Study of the performance and emission characteristics for a dual fuel powered single cylinder diesel engine. International Journal of Automotive and Mechanical Engineering. 2016; 13(2):3373-87.

[20] Bhaskar K, Sendilvelan S, Muthu V, Aravindraj S. Performance and emission characteristics of compression ignition engine using methyl ester blends of jatropha and fish oil. Journal of Mechanical Engineering and Scienes. 2016; 10(2):1984-97.

[21] Yusop A, Mamat R, Mat Yasin M, Ali OM. Effects of particulate matter emissions of diesel engine using diesel-methanol blends. Journal of Mechanical Engineering and Sciences. 2014;6:959-67.

[22] Kamil M, Rahman MM. Effect of Injection Hole Diameter on Operational Conditions of Common-Rail Fuel-Injection System for Port-Injection HydrogenFueled Engine. International Journal of Automotive and Mechanical Engineering. 2015;11:2383-95.

[23] Vashist D, Ahmad M. Statistical Analysis of Diesel Engine Performance for Castor and Jatropha Biodiesel-Blended Fuel. International Journal of Automotive and Mechanical Engineering. 2014;10:2155-69. 
[24] Ibrahim F, Mahmood WMFW, Abdullah S, Mansor MRA. A review of soot particle measurement in lubricating oil. Defence $\mathrm{S}$ and $\mathrm{T}$ Technical Bulletin. 2015;8:141-52.

[25] Ibrahim F, Mahmood WMFW, Abdullah S, Mansor MRA. Soot particle measurement in engine cylinder. Jurnal Teknologi. 2016;78:187-95.

[26] Mahmood W, Faizal WM. Computational studies of soot paths to cylinder wall layers of a direct injection diesel engine: University of Nottingham; 2011.

[27] Mahmood WMFW, LaRocca A, Shayler PJ, Bonatesta F, Pegg I. Predicted paths of soot particles in the cylinders of a direct injection diesel engine. SAE Technical Paper; 2012.

[28] Weber J, Peters N, Bockhorn H, Pittermann R. Numerical simulation of the evolution of the soot particle size distribution in a DI diesel engine using an emulsified fuel of diesel-water. SAE Technical Paper No. 2004-01-1840; 2004.

[29] Cui X, Zhou B, Matsunaga M, Fujii Y, Kusaka J, Daisho Y. A Numerical Study of the Effects of FAME Blends on Diesel Combustion and Emissions Characteristics Using a 3-D CFD Code Combined with Detailed Kinetics and Phenomenological Soot Formation Models. SAE International Journal of Fuels and Lubricants. 2013;6:839-51.

[30] Zuber MA, Mahmood WMFW, Harun Z, Abidin ZZ. Soot particle evolution and transport in a direct injection diesel engine. Jurnal Teknologi. 2015;74:85-8.

[31] Zuber MA, Mahmood WMFW, Harun Z, Abidin ZZ, La Rocca A, Shayler P, et al. Modeling of in-cylinder soot particle size evolution and distribution in a direct injection diesel engine. SAE Technical Paper No. 2015-01-1075; 2015.

[32] Sukumaran S, Kong S-C. Modelling biodiesel-diesel spray combustion using multicomponent vaporization coupled with detailed fuel chemistry and soot models. Combustion Theory and Modelling. 2016;20:913-40.

[33] Raj RTK, Manimaran R. Effect of swirl in a constant speed DI diesel engine using computational fluid dynamics. CFD Letters. 2012;4:214-24.

[34] Tutak W, Jamrozik A. Validation and optimization of the thermal cycle for a diesel engine by computational fluid dynamics modeling. Applied Mathematical Modelling. 2016;40:6293-309.

[35] Zhao F, Yu W, Su W. Sensitivity study of engine soot forming using detailed soot modelling oriented in soot surface growth dynamic. Fuel. 2016;168:81-90.

[36] Sencic T, Medica V, Bukovac O. Soot model validation and development. Advanced Engineering. 2010;4.

[37] Bissoli M, Cuoci A, Frassoldati A, Faravelli T, Ranzi E, Lucchini T, et al. Detailed kinetic analysis of HCCI combustion using a new multi-zone model and CFD simulations. SAE International Journal of Engines. 2013;6:1594-609.

[38] Kawanabe H, Ishiyama T. Computational fluid dynamics analysis of the combustion process and emission characteristics for a direct-injection-premixed charge compression ignition engine. International Journal of Engine Research. 2014;15:539-48.

[39] Wei S, Wang F, Leng X, Liu X, Ji K. Numerical analysis on the effect of swirl ratios on swirl chamber combustion system of DI diesel engines. Energy Conversion and Management. 2013;75:184-90.

[40] Wang Z, Srinivasan KK, Krishnan SR, Som S. A computational investigation of diesel and biodiesel combustion and NOx formation in a light-duty compression ignition engine. Mississippi State University; 2012. 
[41] Ren Y, Abu-Ramadan E, Li X. Numerical simulation of biodiesel fuel combustion and emission characteristics in a direct injection diesel engine. Frontiers of Energy and Power Engineering in China. 2010;4:252-61.

[42] Pang KM, Ng HK, Gan S. In-cylinder diesel spray combustion simulations using parallel computation: A performance benchmarking study. Applied Energy. 2012;93:466-78.

[43] Pang KM, Ng HK, Gan S. Simulation of temporal and spatial soot evolution in an automotive diesel engine using the Moss-Brookes soot model. Energy Conversion and Management. 2012;58:171-84.

[44] Tan SM, Ng HK, Gan S. Computational study of crevice soot entrainment in a diesel engine. Applied Energy. 2013;102:898-907.

[45] Tan SM, Ng HK, Gan S. CFD modelling of soot entrainment via thermophoretic deposition and crevice flow in a diesel engine. Journal of Aerosol Science. 2013;66:83-95.

[46] Richards KJ, Senecal PK, Pomraning E. CONVERGE (v2.2.0). In: Inc. CS, editor. Madison, WI, WI: Convergent Science Inc.; 2014.

[47] Hiroyasu H, Kadota T. Models for combustion and formation of nitric oxide and soot in direct injection diesel engines. SAE Technical Paper; 1976.

[48] Walls J, Strickland-Constable R. Oxidation of carbon between 1000-2400 C. Carbon. 1964;1:333IN23335-334338.

[49] Zuber MA, Mahmood WMFW, Abidin ZZ, Harun Z. In-cylinder soot particle distribution in squish region of a direct injection diesel engine. International Journal of Mechanical and Mechatronics Engineering. 2014;14:51-8.

[50] Heywood J. Internal combustion engine fundamentals: McGraw-Hill Education; 1988.

[51] Reitz RD, Bracco F. Mechanisms of breakup of round liquid jets. Encyclopedia of Fluid Mechanics. 1986;3:233-49.

[52] Ricart L, Xin J, Bower GR, Reitz RD. In-cylinder measurement and modeling of liquid fuel spray penetration in a heavy-duty diesel engine. SAE Technical Paper; 1997.

[53] Liu A, Mather D, Reitz R. Modeling the effects of drop drag and breakup on fuel sprays. Technical paper. Wisconsin Univ., Madison, WI (United States). Engine Research Center; 1993.

[54] Schmidt DP, Rutland C. A new droplet collision algorithm. Journal of Computational Physics. 2000;164:62-80.

[55] Naber J, Reitz RD. Modeling engine spray/wall impingement. SAE Technical Paper; 1988.

[56] Lian ZW, Reitz RD. Modeling Diesel Engine Spray Vaporization and Combustion. SAE Technical Paper; 1992.

[57] Han Z, Reitz RD. Turbulence modeling of internal combustion engines using RNG $\kappa-\varepsilon$ models. Combustion Science and Technology. 1995;106:267-95.

[58] Senecal P, Pomraning E, Richards K, Briggs T, Choi C, McDavid R, et al. Multidimensional modeling of direct-injection diesel spray liquid length and flame liftoff length using CFD and parallel detailed chemistry. SAE Technical Paper; 2003.

[59] CEI. EnSight User Manual for version 10.1. In: Inc. CEI, editor. USA;2013.

[60] Ibrahim F, Mahmood WMFW, Abdullah S, Mansor MRA. Numerical investigation on soot particles emission in compression ignition diesel engine by using particulate mimic soot model. MATEC Web of Conferences: EDP Sciences; 2017. p. 01071. 
[61] Alkidas AC. Relationships between smoke measurements and particulate measurements. SAE Technical Paper; 1984.

[62] Tree DR, Svensson KI. Soot processes in compression ignition engines. Progress in Energy and Combustion Science. 2007;33:272-309.

[63] Xi J, Zhong BJ. Soot in diesel combustion systems. Chemical Engineering andTechnology. 2006;29:665-73.

[64] Ibrahim F, Mahmood WMFW, Abdullah S, Mansor MRA. Investigation of soot particles in compression ignition diesel engine by CFD simulation using different level of complexity of soot models. FISITA 2016 World Automotive Congress. Busan, Korea; 2016.

[65] Symonds JP, Reavell KSJ, Olfert JS, Campbell BW, Swift SJ. Diesel soot mass calculation in real-time with a differential mobility spectrometer. Journal of Aerosol Science. 2007;38:52-68. 